\title{
Occurrence of Pectin Methylesterase in Guavas
}

\author{
Irma G. Rieckehoff and A. Rios ${ }^{1}$
}

INTRODUCTION

Pectin methylesterase has been found to be present in the fruits, leaves, stems, and roots of various plants. Citrus fruits and tomatoes $(1)^{2}$ are among the fruits mentioned in the literature as showing high activities of the enzyme.

The formation of gel-like particles in guava nectars has been observed for some time in this laboratory. When cans of this product are opened, the gel-like particles can be seen suspended in the liquid. These solid particles, which cannot be disintegrated by stirring the nectar well, detract from the appearance of the product.

Rouse (2) reported that gelatinization of citrus concentrates is caused by the action of pectin methylesterase, which partly demethylates the pectin present to form low methoxyl pectin that produces gels in the presence of polyvalent cations. Wenzell, Moore, Rouse, and Atkins (3) subsequently showed that the pectin content, enzyme activity, and the concentration of polyvalent cations were the principal factors responsible for gel formation in citrus concentrates.

The presence of methylesterase in guavas has not been reported before. Since guava nectars of the Dominica Roja variety contain approximately 0.003 to 0.004 percent of $\mathrm{Ca}$ (4) and about 0.3 percent of pectin (as pectic acid), the $\mathrm{pH}$ varies from 3.3 to 3.7 , and the soluble solids are adjusted to $15^{\circ}$ Brix, it was suspected that the formation of gels in the nectars might be due to a reaction similar to that already reported as taking place in citrus concentrates. It was decided to investigate the occurrence of pectin methylesterase in guavas to obtain more information about the possible change taking place in the nectars.

\section{EXPERIMENTAL PROCEDURE}

Whole, ripe, firm guavas of the Dominica variety (both sweet and sour types) were separated by hand into three parts: Peel, shells and inner pulp, and seeds. Each part was homogenized separately in a Waring Blendor and stirred for about 3 minutes with 3 parts of a $0.35-\mathrm{M}$ solution of $\mathrm{NaCl}$. The $\mathrm{pH}$ of the mixtures was adjusted to 8 with dilute $\mathrm{NaOH}$ and the dispersion left overnight at $50^{\circ} \mathrm{F}$. The next day they were filtered and $20 \mathrm{ml}$. of the filtrate were used for the assay. The method used was essentially that pro-

${ }^{1}$ Assistant Chemist and Research Assistant in Chemistry, respectively, Agricultural Experiment Station, University of Puerto Rico, Río Piedras, P. R.

2 Numbers in parentheses refer to Literature Cited, p. 92. 
posed by Kertesz (6). Each $20 \mathrm{ml}$. of the extracts corresponded to $5 \mathrm{gm}$. of the original wet tissue and to $0.75 \mathrm{gm}$. of dry tissue. Fifty milliliters of a 1-percentsolution of Exchange citrus pectin were added. The reaction medium was brought in each case to $\mathrm{pH}$ 6.2. The $\mathrm{pH}$ was kept constant at this value by the addition of $0.05 \mathrm{~N} \mathrm{NaOH}$ with a microburette at 10-minute intervals for 30 minutes, at the end of which time the mixture was rapidly titrated to $\mathrm{pH} 7.5$. The temperature of the reaction medium was $26^{\circ} \mathrm{C}$.

Controls were run by heating the extracts for 3 minutes at $190^{\circ} \mathrm{F}$. and treating them exactly like the samples. The differences between the volumes of $0.05 \mathrm{~N} \mathrm{NaOH}$ needed to titrate the samples and the controls to $\mathrm{pH} 7.5$ were taken as the volumes of $0.05 \mathrm{~N} \mathrm{NaOH}$ which were used by the samples as a result of enzyme activity. Pectin methylesterase units are expressed as milligrams of $\mathrm{OCH}_{3}$ per gram of original wet tissue per 30-minute reaction time. The results of the assays are presented in table 1.

TABLE 1.-Methylesterase content of different parts of guavas of the Dominica Roja variety

\begin{tabular}{l|c|c|c}
\hline Part tested & NaOH consumed & $\begin{array}{c}\text { P. E. units1 per } \\
\text { gram of wet tissue }\end{array}$ & $\begin{array}{c}\text { P. E. units per } \\
\text { gram of dry tissue }\end{array}$ \\
\hline & Meq. & Mfg. & Mfg. \\
Peel & 0.080 & 0.49 & 3.27 \\
Shell & .010 & .06 & .40 \\
Pulp and seeds & .026 & .16 & 1.07 \\
\hline
\end{tabular}

${ }^{1}$ Expressed as milligrams of $\mathrm{OCH}_{3}$ per gram of wet tissue per 30 minutes.

\section{DISCUSSION}

The resultsin table 1 show a noticeable methylesterase activity in guavas ${ }^{*}$ However, this activity is very much less than that of tomatoes, citrus flavedo, etc. The optimum conditions for extraction of the enzyme from the tissues of the guava are not known. The temperature at which the demethylations were carried out was much less than the optimum for enzymes separated from other sources. A complete study of the extraction procedure and the optimum conditions for action of the methylesterase of guavas will soon be undertaken in this Laboratory.

No activity could be found in an extract from the leaves of the guava tree, nor could any be found in the clear filtered juice of the fruit. The highest enzyme activity is apparently located in the peel of the fruit, while the shell shows the least.

The conditions present during processing of guava nectars appear to be favorable to the demethylation of the pectin and subsequent formation of low-methoxyl gels. It takes at least 1 hour in good commercial practice for the guava nectar to be canned, from the time the guavas are ground until 
the moment the nectars are flash-pasteurized. Although enzyme activity seems to be low, the other factors necessary for the formation of low-methoxyl gels are present in the fruit dispersions. Pasteurization procedures used for guava nectars appear to be adequate since no enzyme activity could be detected in the pasteurized nectars.

\section{SUMMARY}

It has been possible to detect the presence of pectin methylesterase in guavas. It is suggested that partial demethoxylation of the pectin in the nectars and subsequent formation of insoluble pectinates with bivalent cations, may be responsible for the formation of insoluble gel-like particles present in some canned guava nectars.

\section{RESUMEN}

Se ha podido demostrar la presencia de la metilesterasa de pectina en la guayaba. Se sugiere que la demetoxilación parcial de la pectina presente en los néctares de guayaba y la subsiguiente formación de pectinatos de iones bivalentes pueden ser responsables de la presencia de los coágulos insolubles que se encuentran en algunos néctares de guayaba enlatados.

\section{LITERATURE CITED}

1. Kertesz, Z. I., The Pectic Substances, table, p. 365, 1951.

2. Rouse, A. H., Proc. Fla. State Hort. Soc., 62nd. Ann. Meet., p. 170, 1949.

3. Wenzel, F. W., Moore, E. L., Rouse, A. H., and Atkins, C. D., Food Tech. 5 454, 1951.

4. Axtmayer, J. H., and Cook, D., Manual de Bromatología, Publicación 186 de la Oficina Sanitaria Panamericana, p. 191, Sept. 1942.

5. Unpublished data, Department of Chemistry, Agr. Exp. Sta., Univ. P. R.

6. Kertesz, Z. I., J. Biol. Chem., 121 589, 1937. 